Vol. 2, No. 1, Januari - Juni 2018

\title{
edureligia
}

\section{METODE PENANAMAN NILAI-NILAI MULTIKULTURAL PADA SISWA KELAS RENDAH (STUDI PADA MI DI MWCNU LP. MAARIF KRAKSAAN)}

\author{
Imam Bukhori ${ }^{1}$ \\ Institut Agama Islam Zainul Hasan Genggong Kraksaan Probolinggo
}

\section{Info Artikel}

Sejarah Artikel:

Diterima Nopember 2017

Disetujui Desember 2017

Dipublikasikan Pebruari 2018

Keywords:

Metode; penanaman nilai

multikultural; kelas rendah

\begin{abstract}
The purpose of the research is to describe the methods of multicultural values implanting for early students in madrasah ibtidaiyahs on MWCNU LP Ma'arif Kraksaan subdistrict. The method that used to succeed the implanting of multicultural values are story telling, playing, study tour, inuring, modelling and reading poems. The most used method is story telling and inuring. The using of those methods are to give mutual understanding for the multicultural values such as openness, humanity, tolerance, mutually help, justness, equality and brotherhood, good thought, and have a great affection to the nation. By using those methods, the students behaviour could be changeable from refusing the others that differents become accepting and friendly with the others. The constrains also appear while impalnting multicultural values, such as the lack of knowledge in story telling techniques media used by teachers, the inconsistency of posture in school and the circumstances where the students live.
\end{abstract}

\begin{abstract}
Abstrak
Tujuan penelitian ini adalah untuk mendeskripsikan metode penanaman nilai multikultural pada siswa usia dini di madrasah ibtidaiyah di kecamatan MWCNU LP Ma'arif Kraksaan. Metode yang digunakan untuk mensukseskan penanaman nilai-nilai multikultural adalah bercerita, bermain, studi tur, inuring, pemodelan dan pembacaan puisi. Metode yang paling banyak digunakan adalah story telling dan inuring. Penggunaan metode-metode tersebut adalah untuk memberikan pengertian bersama untuk nilai-nilai multikultural seperti keterbukaan, kemanusiaan, toleransi, saling membantu, keadilan, kesetaraan dan persaudaraan, pemikiran yang baik, dan memiliki kasih sayang yang besar kepada bangsa. Dengan menggunakan metode tersebut, perilaku siswa dapat berubah dari menolak yang lain yang berbeda menjadi menerima dan ramah dengan yang lain. Kendala-kendala tersebut juga muncul ketika mengimplikasikan nilai-nilai multikultural, seperti kurangnya pengetahuan dalam media teknik bercerita yang digunakan oleh para guru, ketidakkonsistenan postur di sekolah dan keadaan di mana para siswa tinggal.
\end{abstract}




\section{PENDAHULUAN}

Anak merupakan investasi yang sangat penting bagi penyiapan sumber daya manusia di masa depan, (Fauzi, 2018a). Dalam rangka mempersiapakan SDM yang berkualitas untuk masa depan, pendidikan merupakan salah satu hal yang penting untuk diberikan sejak dini. Pendidikan merupakan ladang investasi terbesar dalam membangun dan membentuk manusia seutuhnya bagi anak (Baharun, 2016). Memberikan perhatian yang lebih kepada anak pada masa-masa awal untuk mendapatkan pendidikan, merupakan salah satu langkah yang tepat untuk menyiapkan generasi unggul yang akan meneruskan perjuangan bangsa.

Pada konteks tersebut, peserta didik di tingkat $\mathrm{SD} / \mathrm{MI}$ yang berada di kelas rendah adalah anak yang berada pada rentang usia dini. Massa usia dini ini merupakan masa perkembangan anak yang pendek tetapi masa yang sangat penting bagi kehidupannya, oleh karena itu seluruh potensi yang dimiliki anak perlu didorong agar potensi anak akan berkembang secara optimal. Usia dini merupakan masa keemasan (golden age) yang hanya terjadi satu kali dalam perkembangan kehidupan manusia. Masa ini sekaligus merupakan masa yang kritis dalam perkembangan anak. Jika pada masa ini anak kurang mendapat perhatian dalam hal pendidikan, perawatan, pengasuhan dan layanan kesehatan serta kebutuhan gizinya dikhawatirkan anak tidak dapat tumbuh dan berkembang secara optimal.

Perkembangan dan karakteristik siswa kelas rendah di SD/MI berbeda-beda antara anak yang satu dengan anak yang lainnya. Karakter anak pada masa kelas rendah berbedah dengan karakter anak pada kelas tinggi. Oleh karena itu, diperlukan pola pendidikan karakter yang efektif dalam menciptakan karakter peserta didik sesuai dengan harapan (Baharun, 2017). Hal ini dapat dilihat dalam proses pembelajaran anak. Pada usia SD/MI utamanya yang ada di kelas rendah belum dapat mengembangkan keterampilan kognitifnya secara penuh, tetapi anak di kelas rendah belum dapat mengembangkan keterampilan kognitifnya secara penuh, akan tetapi anak di kelas tinggi sudah dapat berfikir dan berkreasi secara luas. Salah satu bagian penting yang harus mendapatkan perhatian terkait dengan pendidikan yang diberikan sejak usia dini adalah penanaman nilai-nilai multikultural, (Ahmad, 2017).
Pendidikan multikultural yang dilakukan sejak usia dini, diharapkan pada tahap perkembangan selanjutnya anak akan mampu menerima perbedaan, terutama terkait dengan identitas diri, lingkungan dan orang-orang di sekitarnya, sehingga ia dapat menerapkan dan menerima perbedaaan itu dalam kehidupan sehari-hari. Hal itu akan berpengaruh pada mudah tidaknya anak diterima oleh masyarakat sekitarnya dalam hal bersosialisasi.

\section{KAKAKTERISTIK PEMBELAJARAN PESERTA DIDIK DI SD/MI}

Pembentukan kemampuan siswa di sekolah dapat dipengaruhi oleh proses belajar yang ditempuhnya. Proses belajar akan terbentuk berdasarkan pandangan dan pemahaman guru tentang karakteristik siswa dan juga hakikat pembelajaran. Untuk menciptakan proses belajar yang efektif, hal yang harus dipahami guru adalah fungsi dan peranannya dalam kegiatan belajar mengajar, yaitu sebagai pembimbing, fasilitator, nara sumber, atau pemberi informasi. Proses belajar yang terjadi tergantung pada pandangan guru terhadap makna belajar yang akan mempengaruhi aktivitas siswa-siswanya. Dengan demikian, proses belajar perlu disesuaikan dengan tingkat perkembangan siswa. Untuk mendukung hal tersebut, diperlukan pemahaman para guru mengenai karakteristik siswa dan proses pembelajarannya, khususnya di SD/MI kelas rendah.

Tingkatan kelas di sekolah dasar dapat dibagi menjadi dua, yaitu kelas rendah dan kelas tinggi. Kelas rendah terdiri dari kelas satu, dua, dan tiga, sedangkan kelas-kelas tinggi terdiri dari kelas empat, lima, dan enam. Di Indonesia, rentang usia siswa SD, yaitu antara 6 atau 7 tahun sampai 12 tahun. Usia siswa pada kelompok kelas rendah, yaitu 6 atau 7 sampai 8 atau 9 tahun. Siswa yang berada pada kelompok ini termasuk dalam rentangan anak usia dini. Masa usia dini ini merupakan masa yang pendek tetapi sangat penting bagi kehidupan seseorang. Oleh karena itu, pada masa ini seluruh potensi yang dimiliki anak perlu didorong sehingga akan berkembang secara optimal.

Berkaitan dengan hal tersebut, Pendidikan dan pembelajaran yang berkarakter sudah saatnya diberikan kepada peserta didik dengan mengintegrasikan antara materi ajar, bahan ajar, metode, media, dengan kondisi real di mana peserta didik hidup (Hasan Baharun, Vidyatul Muyassaroh, 2018). 
Makmun (2007) mengungkapkan bahwa ada beberapa tugas perkembangan siswa yang harus difasilitasi oleh sekolah, diantaranya: (a) mengembangkan konsep-konsep yang perlu bagi kehidupan sehari-hari, (b) mengembangkan kata hati, moralitas, dan suatu skala, nilai-nilai, (c) mencapai kebebasan pribadi, (d) mengembangkan sikap-sikap terhadap kelompok-kelompok dan institusi-institusi sosial. Dari sekolah inilah kemudian, beberapa keterampilan akan dimiliki oleh anak yang sudah mencapai tugas-tugas perkembangan pada masa kanakkanak akhir dengan rentang usia 6-13 tahun. Keterampilan yang dicapai diantaranya, yaitu social-help skills dan play skill (Soesilowindradini, 2003).

Social-help skills berguna untuk membantu orang lain di rumah, di sekolah, dan di tempat bermain seperti membersihkan halaman dan merapikan meja kursi. Keterampilan ini akan menambah perasaan harga diri dan menjadikannya sebagai anak yang berguna, sehingga anak suka bekerja sama (bersifat kooperatif). Dengan keterampilan ini pula, anak telah dapat menunjukkan keakuannya tentang jenis kelamin, mulai berkompetisi dengan teman sebaya, mempunyai sahabat, mampu berbagi, dan mandiri. Sementara itu, play skill terkait dengan kemampuan motorik seperti melempar, menangkap, berlari, keseimbangan. Anak yang terampil dapat membuat penyesuaian-penyesuaian yang lebih baik di sekolah dan di masyarakat. Anak telah dapat melompat dengan kaki secara bergantian, dapat mengendarai sepeda roda dua, dapat menangkap bola dan telah berkembang koordinasi tangan dan mata untuk dapat memegang pensil maupun memegang gunting, (Soesilowindradini, 2003).

Pertumbuhan fisik sebagai salah satu karakteristik perkembangan siswa kelas rendah biasanya telah mencapai kematangan. Anak telah mampu mengontrol tubuh dan keseimbangannya. Untuk perkembangan emosi, anak usia 6-8 tahun biasanya telah dapat mengekspresikan reaksi terhadap orang lain, mengontrol emosi, mau dan mampu berpisah dengan orang tua, serta mulai belajar tentang benar dan salah. Perkembangan kecerdasan siswa kelas rendah ditunjukkan dengan kemampuannya dalam melakukan seriasi, mengelompokkan obyek, berminat terhadap angka dan tulisan, meningkatnya perbendaharaan kata, senang berbicara, memahami sebab akibat dan berkembangnya pemahaman terhadap ruang dan waktu.
Pembelajaran di kelas rendah dilaksanakan berdasarkan rencana pelajaran yang telah dikembangkan oleh guru. Proses pembelajaran harus dirancang guru sehingga kemampuan siswa, bahan ajar, proses belajar, dan sistem penilaian sesuai dengan tahapan perkembangan siswa. Hal lain yang harus dipahami, yaitu proses belajar harus dikembangkan secara interaktif. Dalam hal ini, guru memegang peranan penting dalam menciptakan stimulus respon agar siswa menyadari kejadian di sekitar lingkungannya. Siswa kelas rendah masih banyak membutuhkan perhatian karena focks konsentrasinya masih kurang, perhatian terhadap kecepatan dan aktivitas belajar juga masih kurang. Hal ini memerlukan kegigihan guru dalam menciptakan proses belajar yang lebih menarik dan efektif. Piaget dalam Woolfolkmenyatakan bahwa setiap anak memiliki cara tersendiri dalam menginterpretasikan dan beradaptasi dengan lingkungannya. Menurutnya, setiap anak memiliki struktur kognitif yang disebut schemata, yaitu sistem konsep yang ada dalam pikiran ebagai hasil pemahaman terhadap objek yang ada dalam lingkungannya. Pemahaman tentang objek tersebut berlangsung melalui proses asimilasi (menghubungkan objek dengan konsep yang sudah ada dalam pikiran) dan akomodasi (proses memanfaatkan konsep-konsep dalam pikiran untuk menafsirkan objek). Kedua proses tersebut jika berlangsung terus menerus akan membuat pengetahuan lama dan pengetahuan baru menjadi seimbang. Dengan cara seperti itu secara bertahap anak dapat membangun pengetahuan melalui interaksi dengan lingkungannya. Berdasarkan uraian tersebut, maka perilaku belajar anak sangat dipengaruhi oleh aspek-aspek dari dalam dirinya dan lingkungannya. Kedua hal tersebut tidak mungkin dipisahkan karena memang proses belajar terjadi dalam konteks interaksi diri anak dengan lingkungannya.

Anak usia sekolah dasar berada pada tahapan operasional konkret. Pada rentang usia tersebut anak mulai menunjukkan perilaku belajar sebagai berikut: (1) Mulai memandang dunia secara objektif, bergeser dari satu aspek situasi ke aspek lain secara reflektif dan memandang unsur-unsur secara serentak, (2) Mulai berpikir secara operasional, (3) Mempergunakan cara berpikir operasional untuk mengklasifikasikan benda-benda, (4) Membentuk dan mempergunakan keterhubungan aturan-aturan, prinsip ilmiah sederhana, dan mempergunakan hubungan sebab akibat, dan (5) Memahami konsep 
substansi, volume zat cair, panjang, lebar, luas, dan berat (Woolfolk, 2009).

Memperhatikan tahapan perkembangan berpikir, lebih lanjut Woolfolk (2009)kecenderungan belajar anak usia sekolah dasar memiliki tiga ciri, yaitu:

\section{Konkrit}

Konkrit mengandung makna proses belajar beranjak dari hal-hal yang konkrit yakni yang dapat dilihat, didengar, dibaui, diraba, dan diotak atik, dengan titik penekanan pada pemanfaatan lingkungan sebagai sumber belajar. Pemanfaatan lingkungan akan menghasilkan proses dan hasil belajar yang lebih bermakna dan bernilai, sebab siswa dihadapkan dengan peristiwa dan keadaan yang sebenarnya, keadaan yang alami, sehingga lebih nyata, lebih faktual, lebih bermakna, kebenarannya lebih dapat dipertanggung jawabkan.

\section{Integratif}

Pada tahap usia sekolah dasar anak memandang sesuatu yang dipelajari sebagai suatu keutuhan, mereka belum mampu memilah-milah konsep dari berbagai disiplin ilmu, hal ini melukiskan cara berpikir anak yang deduktif yakni dari hal umum ke bagian demi bagian.

\section{Hierarkis}

Pada tahapan usia sekolah dasar, cara anak belajar berkembang secara bertahap mulai dari hal-hal yang sederhana ke hal-hal yang lebih kompleks. Sehubungan dengan hal tersebut, maka perlu diperhatikan mengenai urutan logis, keterkaitan antar materi, dan cakupan keluasan serta kedalaman materi .

Kebermaknaan belajar sebagai hasil dari peristiwa mengajar ditandai oleh terjadinya hubungan antara aspek-aspek, konsepkonsep, informasi atau situasi baru dengan komponen-komponen yang relevan di dalam struktur kognitif siswa. Proses belajar tidak sekadar menghafal konsep-konsep atau faktafakta belaka, tetapi merupakan kegiatan menghubungkan konsep-konsep untuk menghasilkan pemahaman yang utuh, sehingga konsep yang dipelajari akan dipahami secara baik dan tidak mudah dilupakan. Pelajaran harus dikaitkan dengan konsep-konsep yang sudah dimiliki siswa, sehingga konsep-konsep baru tersebut benarbenar terserap oleh siswa. Dengan demikian, agar terjadi belajar bermakna maka guru harus selalu berusaha mengetahui dan menggali konsep-konsep yang telah dimiliki siswa dan membantu memadukannya secara harmonis konsep-konsep tersebut dengan pengetahuan baru yang akan diajarkan.

Pengembangan sikap ilmiah pada siswa kelas rendah dapat dilakukan dengan cara menciptakan pembelajaran yang memungkinkan siswa berani mengemukakan pendapat, memiliki rasa ingin tahu, memiliki sikap jujur terhadap dirinya dan orang lain, dan mampu menjaga kebersihan diri dan lingkungan. Dalam pengembangan kreativitas siswa, proses pembelajaran dapat diarahkan sesuai dengan tingkat perkembangannya, misalnya memecahkan permasalahan melalui permainan sehari-hari. Dari sini belajar akan lebih bermakna jika anak mengalami langsung apa yang dipelajarinya dengan mengaktifkan lebih banyak indera, daripada hanya mendengarkan penjelasan dari guru. Esensi proses pembelajaran di kelas rendah adalah pembelajaran kongkret, yaitu suatu pembelajaran yang dilaksanakan secara logis dan sistematis untuk membelajarkan siswa yang berkenaan dengan fakta dan kejadian di lingkungan sekitar siswa. Pembelajaran kongkret lebih sesuai bila diberikan pada siswa kelas rendah. Kondisi pembelajaran ini harus diupayakan oleh guru sehingga kemampuan siswa, bahan ajar, proses belajar, dan sistem penilaian sesuai dengan tahap perkembangan siswa.

Pendidikan pada siswa kelas rendah bertujuan membimbing dan mengembangkan potensi setiap anak agar dapat berkembang secara optimal sesuai tipe kecerdasannya. Oleh karena itu pendidik atau guru harus memahami kebutuhan khusus atau kebutuhan individual anak. Akan tetapi, perlu disadari pula bahwa ada faktor-faktor yang sulit atau tidak dapat dirubah dalam diri anak yaitu faktor genetis. Karena itulah pendidikan pada siswa kelas rendah diarahkan untuk memfasilitasi setiap anak dengan lingkungan dan bimbingan belajar yang tepat agar anak dapat berkembang sesuai kapasitas genetisnya. Siswa kelas rendah dipandang sebagai individu yang baru mulai mengenal dunia. Ia belum mengetahui tata krama, sopan santun, aturan, norma, etika, dan berbagai hal lain yang terkait dengan kehidupan duniawi. Pada usia ini merupakan masa bagi seorang anak untuk belajar berkomunikasi dengan orang lain serta memahaminya. Karena itu seorang anak perlu dibimbing agar mampu memahami berbagai hal tentang kehidupan dunia dan segala isinya.

Dalam membimbing dan mengembangkan potensi siswa kelas rendah perlu memilih 
metode yang tepat. Pemilihan metode yang dilakukan pendidik atau guru semestinya dilandasi alasan yang kuat dan faktor-faktor pendukungnya seperti karakteristik tujuan kegiatan dan karakteristik anak yang diajar. Karakteristik tujuan adalah pengembangan kognitif, pengembangan kreativitas, pengembangan bahasa, pengembangan emosi, pengembangan motorik, dan pengembangan nilai serta pengembangan sikap dan perilaku. Untuk mengembangkan nilai dan sikap anak dapat dipergunakan metode-metode yang memungkinkan terbentuknya kebiasaan-kebiasaan yang didasari oleh nilai-nilai multikulturalisme agar anak dapat menjalani kehidupan sesuai dengan norma yang berlaku di masyarakat.

Setiap guru akan menggunakan metode sesuai dengan gaya melaksanakan kegiatan. Tetapi yang harus diingat bahwa siswa kelas rendah memiliki cara yang khas. Oleh karena itu ada metode-metode yang lebih sesuai bagi anak kelas rendah dibandingkan dengan metode-metode lain. Misalnya saja guru pada kelas rendah jarang sekali yang menggunakan metode ceramah. Orang akan segera menyadari bahwa metode ceramah tidak sesuai dan tidak banyak berarti apabila diterapkan untuk anak siswa kelas rendah.

Metode-metode yang memungkinkan anak dapat melakukan hubungan atau sosialisasi dengan yang lain akan lebih sesuai dengan kebutuhan dan minat anak. Melalui kedekatan hubungan guru dan anak, seorang guru akan dapat mengembangkan kekuatan pendidik yang sangat penting. Dalam pelaksanaan penanaman nilai-nilai multikultural pada siswa kelas rendah banyak metode yang dapat digunakan oleh guru atau pendidik. Namun sebelum memilih dan menerapkan metode yang ada perlu diketahui bahwa guru atau pendidik harus memahami metode yang akan dipakai, karena ini akan berpengaruh terhadap optimal tidaknya keberhasilan penanaman nilai-nilai multikultural tersebut.

Metode dalam penanaman nilai-nilai multikultural kepada siswa kelas rendah sangatlah bervariasi, diantaranya bercerita, bernyanyi, bermain, bersajak dan karya wisata. Masing-masing metode mempunyai kelemahan dan kelebihan. Penggunaan salah satu metode penanaman nilai moral yang dipilih tentunya disesuaikan dengan kondisi sekolah atau kemampuan seorang guru dalam menerapkannya. Penjelasan lebih rinci masing-masing metode tersebut sebagai berikut:
Pertama, metode bercerita. Bercerita dapat dijadikan metode untuk menyampaikan nilainilai yang berlaku dalam masyarakat (Hidayat, 2010). Dalam cerita atau dongeng dapat ditanamkan berbagai macam nilai moral, nilai agama, nilai sosial, nilai budaya, dan sebagainya. Ketika bercerita seorang guru juga dapat menggunakan alat peraga untuk mengatasi keterbatasan anak yang belum mampu berpikir secara abstrak. Alat peraga yang digunakan antara lain, boneka, tanaman, benda-benda tiruan, dan lain-lain. Selain itu guru juga bisa memanfaatkan kemampuan olah vokal yang dimiliknya untuk membuat cerita itu lebih hidup, sehingga lebih menarik perhatian siswa.

Kedua, metode bernyanyi. Metode bernyanyi adalah suatu pendekatan pembelajaran secara nyata yang mampu membuat anak senang dan bergembira (Sukarsih, 2002). Anak diarahkan pada situasi dan kondisi psikis untuk membangun jiwa yang bahagia, senang menikmati keindahan, mengembangkan rasa melalui ungkapan kata dan nada. Pesanpesan pendidikan berupa nilai dan moral yang dikenalkan kepada anak tentunya tidak mudah untuk diterima dan dipahami secara baik. Anak tidak dapat disamakan dengan orang dewasa. Anak merupakan pribadi yang memiliki keunikan tersendiri. Pola pikir dan kedewasaan seorang anak dalam menentukan sikap dan perilakunya juga masih jauh dibandingkan dengan orang dewasa. Anak tidak cocok hanya dikenalkan tentang nilai dan moral melalui ceramah atau tanya jawab saja.

Ketiga, metode bersajak atau syair. Pendekatan pembelajaran melalui kegiatan membaca sajak merupakan salah satu kegiatan yang akan menimbulkan rasa senang, gembira, dan bahagia pada diri anak (Anitah, 2011). Secara psikologis siswa kelas rendah sangat haus dengan dorongan rasa ingin tahu, ingin mencoba segala sesuatu, dan ingin melakukan sesuatu yang belum pernah dialami atau dilakukannya. Melalui metode sajak guru bisa menanamkan nilai-nilai multikultutral kepada anak. Sajak ini merupakan metode yang juga membuat anak merasa senang, gembira dan bahagia. Melalui sajak anak dapat dibawa ke dalam suasana indah, halus, dan menghargai arti sebuah seni. Disamping itu anak juga bisa dibawa untuk menghargai makna dari untaian kalimat yang ada dalam sajak itu. Secara nilai, melalui sajak anak akan memiliki kemampuan untuk menghargai perasaan, karya serta keberanian untuk mengungkap 
sesuatu melalui sajak sederhana (Hidayat, 2010).

Keempat, metode karyawisata. Metode karya wisata bertujuan untuk mengembangkan aspek perkembangan anak yang sesuai dengan kebutuhannya (Roestiyah, 2001). Misalnya pengembangan aspek kognitif, bahasa, kreativitas, emosi, kehidupan bermasyarakat, dan penghargaan pada karya atau jasa orang lain. Tujuan berkarya wisata ini perlu dihubungkan dengan tema-tema yang sesuai dengan pengembangan aspek perkembangan anak. Tema yang sesuai adalah tema: binatang, pekerjaan, kehidupan kota atau desa, pesisir, dan pegunungan. Kelima, pembiasaan dalam berperilaku. Kurikulum yang berlaku untuk siswa kelas rendah, lebih banyak dilakukan melalui pembiasaan-pembiasaan tingkah laku dalam proses pembelajaran, (Fauzi, 2009). Ini dapat dilihat misalnya, pada berdoa sebelum dan sesudah belajar, berdoa sebelum makan dan minum, mengucap salam kepada guru dan teman, berbaris sebelum masuk kelas dan sebagainya. Pembiasaan ini hendaknya dilakukan secara konsisten. Jika anak melanggar segera diberi peringatan.

Keenam, metode bermain. Dalam bermain ternyata banyak sekali terkandung nilai-nilai multikultural, diantaranya mau mengalah, kerjasama, tolong menolong, budaya antri, menghormati teman (Anitah, 2011). Nilai multikultural tolong menolong terjadi manakala siswa membantu teman lainnya yang lebih membutuhkan untuk satu jenis mainan. Pengertian dan pemahaman terhadap nilai multikultural tolong menolong adalah salah satu hal yang harus ditanamkan sejak dini. Ketujuh, metode outbond. Metode Outbond merupakan suatu kegiatan yang memungkinkan anak untuk bersatu dengan alam. Melalui kegiatan outbond siswa alan dengan leluasa menikmati segala bentuk tanaman, hewan, dan mahluk ciptaan Allah yang lain (Anitah, 2011). Cara ini dilakukan agar anak tidak hanya memahami apa yang diceritakan atau dituturkan oleh guru atau pendidik di dalam kelas. Melainkan mereka diajak langsung melihat atau memperhatikan sesuatu yang sebelumnya pernah diceritakan di dalam kelas, sehingga apa yang terjadi di kelas akan ada sinkronisasi dengan apa yang tampak di lapangan atau alam terbuka.

Kedelapan, bermain peran. Bermain peran merupakan salah satu metode yang digunakan dalam menanamkan nilai multikultural kepada siswa kelas rendah. Dengan bermain peran anak akan mempunyai kesadaran merasakan jika ia menjadi seseorang yang dia perankan dalam kegiatan bermain peran. Misalnya tema bermain peran tentang kasih sayang dalam keluarga. Anak akan merasakan bagaimana seorang ayah harus menyayangi anggota keluarga, bagaimana seorang ibu harus menyayangi keluarga, begitu juga bagaimana dengan anak-anaknya.

Kesembilan, metode diskusi. Diskusi yang dimaksud di sini adalah mendiskusikan tentang suatu peristiwa (Anitah, 2011). Biasanya dilakukan dengan cara siswa diminta untuk memperhatikan sebuah tayangan dari $\mathrm{CD}$, kemudian setelah selesai siswa diajak berdiskusi dengan guru tentang isi tayangan $\mathrm{CD}$ tersebut. Isi diskusinya antara lain mengapa hal tersebut dilakukan, mengapa anak itu dikatakan baik, mengapa harus menyayangi dan sebagainya. Kesepuluh, metode teladan. Guru yang ideal adalah mereka yang dapat menempatkan dirinya sebagai fasilitator, pemimpin, orang tua dan bahkan tempat menyandarkan kepercayaan, serta membantu orang lain dalam melakukan refleksi (Cahyono, 1995). Guru hendaknya menjadi figur yang dapat dicontoh dalam bertingkah laku oleh siswanya. Secara kodrati manusia merupakan makhluk peniru atau suka melakukan hal yang sama terhadap sesuatu yang dilihat. Apalagi anak-anak, ia akan senantiasa dan sangat mudah meniru sesuatu yang baru dan belum pernah dikenalnya, baik itu perilaku maupun ucapan orang lain.

\section{NILAI NILAI PENDIDIKAN MULTIKULTURAL DI SD/MI}

Pendidikan multikultural adalah suatu pendekatan progresif untuk melakukan transformasi pendidikan yang secara menyeluruh membongkar kekurangan, kegagalan, dan praktik-praktik diskriminasi dalam proses pendidikan (Baharun \& Awwaliyah, 2017). Keragaman-keragaman yang ada, sering disebutkan dengan istilah yang berbeda-beda (Muali, 2017). Menurut Yusri (2008), ada tiga istilah yang sering digunakan untuk menggambarkan masyarakat yang terdiri dari agama, ras, bahasa, budaya yang berbeda, yakni pluralitas (plurality), keragaman (diversity), dan multikultural (multicultural). Ketigatiganya sama-sama merepresentasikan hal sama yaitu keadaan lebih dari satu atau jamak. Keragaman itu berpengaruh terhadap tingkah laku, sikap, dan pola pikir manusia, sehingga manusia memiliki cara-cara (usage), kebiasaan (folk ways), aturan-aturan (mores) 
bahkan adat istiadat (customs) yang berbeda satu sama lain. Bilamana keadaan di atas tidak dapat dipahami dengan baik oleh pihak satu dan lainnya, maka akan sangat rawan terjadi persinggungan-persinggungan yang kemudian berbuah pada adanya konflik, (Hanum, 2011).

Disinilah perlu kiranya nilai-nilai multikultural mengambil perannya. Nilai multikultural selalu menegakkan dan menghargai pluralisme, demokrasi, dan humanisme, (Fauzi, 2018b). Kemudian dengan ketiga hal tersebut diharapkan menjadi generasi yang selalu menjunjung tinggi moralitas, kedisiplinan, kepedulian humanistik, dan kejujuran dalam berperilaku sehari-hari (Hanum, 2011). Beberapa nilainilai multikultural yang ada, sekurangkurangnya terdapat indikator-indikator sebagai berikut: belajar hidup dalam perbedaan, membangun saling percaya (mutual trust), memelihara saling pengertian (mutual understanding) dan menjunjung sikap saling menghargai (mutual respect) terbuka dalam berpikir, apresiasi dan interdepedensi, resolusi konflik dan rekonsiliasi nir kekerasan (Tilaar, 2004).

Sedangkan untuk memahami nilai-nilai multikultural secara umum terdapat empat nilai inti (core values) antara lain, (Fauzi, 2016a): Pertama, apresiasi terhadap adanya kenyataan pluralitas budaya dalam masyarakat. Kedua, pengakuan terhadap harkat manusia dan hak asasi manusia. Ketiga, pengembangan tanggung jawab masyarakat dunia. Keempat, pengembangan tanggung jawab manusia erhadap planet bumi. Selain itu nilai-nilai inti dari pendidikan multikultural adalah demokratis, humanisme, pluralisme (Hanum, 2011). Adapun dalam pendidikan multikultural, proses nilai yang ditanamkan berupa cara hidup menghormati, tulus, toleran terhadap keragaman budaya yang hidup di tengahtengah masyarakat yang plural. Kemudian siswa nantinya juga diharapkan menjadi generasi yang menjunjung tinggi moralitas, kedisiplinan, kepedulian humanistik, dan kejujuran dalam berperilaku sehari-hari, (Fauzi, 2016b).

Nilai-nilai multikultural yang ada dan dikembangkan di SD/MI antara lain belajar hidup dalam perbedaan, membangun saling percaya (mutual trust), memelihara saling pengertian (mutual understanding), menjunjung sikap saling menghargai (mutual respect), terbuka dalam berpikir, apresiasi dan interdepedensi, resolusi konflik dan rekonsiliasi nir kekerasan. Dan juga dengan empat nilai inti (core values) nilai-nilai multikultural yang telah disebutkan dalam pembahasan terdahulu, yaitu: Pertama, apresiasi terhadap adanya kenyataan pluralitas budaya dalam masyarakat. Kedua, pengakuan terhadap harkat manusia dan hak asasi manusia. Ketiga, pengembangan tanggung jawab masyarakat dunia. Keempat, pengembangan tanggung jawab manusia terhadap planet bumi.

Berdasarkan beberapa pendapat yang ada, maka indikator keterlaksanaan nilai-nilai multikultural yang ada di sekolah dasar, adalah sebagai berikut:

\section{Nilai keterbukaan}

Nilai ini memandang bahwa kebenaran yang dianut oleh suatu kelompok, dianut juga oleh kelompok lain. Nilai ini mengakui terhadap pluralisme dalam suatu komunitas atau kelompok sosial, menjanjikan dikedepankannya prinsip inklusifitas yang bermuara pada tumbuhnya kepekaan terhadap berbagai kemungkinan unik yang ada.

\section{Nilai kemanusiaan}

Kemanusiaan manusia pada dasarnya adalah pengakuan akan pluralitas, heterogenitas, dan keragaman manusia itu sendiri. Keragaman itu bisa berupa ideologi, agama, paradigma, suku bangsa, pola pikir, kebutuhan, tingkat ekonomi, dan sebagainya.

\section{Nilai toleransi}

Toleransi merupakan kemampuan untuk dapat enghormati sifat-sifat dasar, keyakinan, dan perilaku yang dimiliki orang lain. Selain itu, toleransi juga bisa dipahami sebagai sifat atau sikap menghargai, membiarkan atau membolehkan pendirian (pandangan, pendapat, kepercayaan kebiasaan, kelakuan dan sebagainya) orang lain yang bertentangan dengan kita. Atau dengan kata lain, hakikat toleransi adalah hidup berdampingan secara damai (peaceful coexistence) dan saling menghargai di antara keragaman (mutual respect).

\section{Nilai tolong menolong}

Sebagai makhluk sosial, manusia tak bisa hidup sendirian meski segalanya ia miliki. Harta benda berlimpah sehinggasetiap saat apa yang ia mau dengan mudah dapat terpenuhi, tetapi ia tidak bisa hidup sendirian tanpa bantuan orang lain dan kebahagiaan pun mungkin tak akan pernah ia rasakan(Fauzi, 2017).

Nilai Keadilan 
Keadilan merupakan sebuah istilah yang menyeluruh dalam segala bentuk, baik keadilan budaya, politik, maupun sosial. Keadilan sendiri merupakan bentuk bahwa setiap insan mendapatkan apa yang ia butuhkan, bukan apa yang ia inginkan.

Nilai persamaan dan persaudaraan

Dalam Islam, istilah persamaan dan persaudaraan itudikenal dengan nama ukhuwah. Ada tiga jenis ukhuwah dalam kehidupan manusia, yaitu: ukhuwah islamiah (persaudaraan seagama), ukhuwah wathaniyyah (persaudaraan sebangsa), ukhuwah bashariyah (persaudaraan sesama manusia). Dari konsep ukhuwah itu, dapat disimpulkan bahwa setiap manusia baik yang berbeda suku, agama, bangsa, dan keyakinan adalah saudara. Karena antarmanusia adalah saudara, setiapmanusia memiliki hak yang sama.

\section{Berbaik sangka}

Memandang seseorang atau kelompok lain dengan melihat pada sisi positifnya dan dengan paradigma itu maka tidak akan ada antar satu kelompok dengan kelompok lain akan saling menyalahkan. Sehingga kerukunan dan kedamaian pun akan tercipta.

Cinta tanah air

Cinta tanah air dalam hal ini tidak bermakna sempit, bukan chauvanisme yang membangga-banggakan negerinya sendiri dan menghina orang lain, bukan pula memusuhi negara lain. Akan tetapi rasa kebangsaan yang lapang dan berperikemanusiaan yang mendorong untuk hidup rukun dan damai dengan bangsabangsa lain.

\section{METODE PENELITIAN}

Penelitian yang dilakukan merupakan penelitian deskriptif dengan menggunakan pendekatan kualitatif. Subjek penelitian adalah para guru di empat Madrasah Ibtidaiyah yang ada di bawah naungan MWCNU LP. Ma'arif Kota Kraksaan pada semester gasal Tahun pelajaran 2017/2018. Keempat MI tersebut meliputi: MINU Kraksaan, MI Zainul Anwar Alassumur Kulon, MI Tarbiaytul Islam Kandangjati Kulon dan MI Mambaul Ulum Alassumur Kulon. Data dikumpulkan melalui observasi, wawancara, dan dokumentasi. Wawancara digunakan untuk menjaring data atau informasi yang berkaitan dengan metode penanaman nilai-nilai multikultural, pengaruh terhadap keberhasilan penanaman nilai-nilai multikultural, dan kendala-kendala yang dihadapi. Teknik pemeriksaan keabsahan data yang digunakan adalah teknik triangulasi, yaitu teknik pemeriksaan keabsahan data yang memanfaatkan sesuatu yang lain di luar data itu untuk keperluan pengecekan atau sebagai pembanding terhadap data itu. Teknik triangulasi yang digunakan dalam penelitian ini adalah triangulasi metode, yaitu dengan cara mengecek ulang informasi hasil pengamatan dan wawancara dengan dokumentasi. Teknik analisis data yang digunakan dalam penelitian ini adalah teknik analisis induktif, yaitu analisis yang bertolak dari data dan bermuara pada simpulan-simpulan umum.

\section{HASIL PENELITIAN DAN PEMBAHASAN}

Berdasarkan penelitian yang telah dilakukan menunjukkan bahwa nilai-nilai multikultural yang pang banyak ditanamkan adalah toleransi, tolong menolong, persamaan dan persaudaraan, serta cinta tanah air, (Ahmad, 2017). Adapun metode yang dipakai dalam menanamkan nilai-nilai multikultural tersebut kepada siswa adalah sebagai berikut: bercerita, bernyanyi, karyawisata, syair, bermain, outbond, bermain peran, diskusi, pembiasaan perilaku, dan teladan. Dari berbagai macam metode penanaman nilainilai multikultural tersebut yang paling sering digunakan adalah metode bercerita dan pembiasaan perilaku.

Metode penananaman nilai-nilai multikultural di atas banyak membawa pengaruh yang positif terhadap perkembangan anak dalam menerima keberagaman. Adapun metode yang digunakan oleh masing-masing sekolah tidak sama, artinya ada penonjolan atau pengutamaan penggunaan metode-metode tertentu di sekolah sesuai dengan kebutuhan dan kemampuan guru dalam melaksanakan metode tersebut. Selain itu penggunaan metode dalam penanaman nilai moral tersebut disesuaikan juga dengan karakteristik masing-masing anak di sekolah tersebut.

Misalnya nilai multikultural yang ditanamkan melalui cerita. Jika dibawakan dengan baik oleh sang guru maka nilai multikultural yang terkandung di dalam cerita tersebut dapat dipahami oleh anak dengan baik. Sebaliknya, apabila guru atau pendidik kurang menguasai teknik bercerita maka nilai multikultural yang hendak disampaikan kurang berhasil dengan baik, bahkan anak cenderung bermain sendiri tidak 
memperhatikan cerita yang disampaikan oleh guru. Oleh karena itu, menurut Husnawiyah (Guru Kelas I-A MINU), dalam penyampaian nilai moral melalui cerita seorang guru disamping harus paham dengan nilai moral yang hendak disampaikan, ia juga harus menguasai dengan baik teknik dalam bercerita. Dengan demikian lambat laun dengan berjalannya waktu anak akan merubah perilakunya yang semula tidak sesuai dengan nilai yang ada menjadi lebih baik sesuai dengan tokoh yang diperankan dalam cerita.

Selain itu menurut Juma'ati (Guru Kelas I MI Mambaul Ulum) Dengan pembiasaanpembiasaan berperilaku juga lambat laun anak akan merubah perilaku kurang baik yang kadang-kadang dibawa dari lingkungan rumahnya menjadi perilaku yang baik sesuai dengan yang diharapkan. Demikian dengan metode-metode yang lainnya. Akan tetapi dari metode-metode penanaman nilai-nilai multikultural yang dilakukan tersebut menurut guru dari keempat MI yang menjadi subjek penelitian menyatakan bahwa menurutnya metode bercerita adalah yang paling efektif. Hal ini dikatakan oleh Zuhdi (Guru Kelas II MI Zainul Anwar) yang mengungkapkan bahwa metode cerita dianggap paling efektif karena anak-anak lebih tertarik dengan metode tersebut dibandingkan dengan metode penanaman nilai-nilai multikultural yang lain. Meskipun dengan menggunakan metode ini seorang guru harus lebih memahami dahulu nilai-nilai multikultural yang hendak ditanamkan dan penguasaan teknik becerita. Teknik bercerita ini, menurut Endah (Guru Kelas I MI Tarbiyatul Islam), misalnya dapat dilihat ketika seorang guru mengisahkan tokoh yang sedang bersedih, maka ia harus mampu membawa siswa untuk menghayati dan hanyut dalam perasaan sedih seperti yang dirasakan oleh tokoh yang sedang diceritakan. Sebaliknya, ketika seorang guru menceritakan tokoh yang sedang memiliki rasa gembira, maka guru harus dapat membawa siswa untuk turut serta merasakan kegembiraan yang dirasakan oleh seorang tokoh.

Metode yang telah dilakukan guru dari keempat MI tersebut dalam menanamkan nilai-nilai multikultural kepada siswanya tentunya tidaklah berjalan secara mulus. Dalam suatu proses tidak akan terlepas dari suatu kendala. Adapun kendala yang dihadapi oleh guru-guru MI di lapangan ketika akan menerapkan metode penanaman nilai-nilai multikultural sangat beragam.
Menurut Nanik Heriati (Guru Kelas I-C MINU) ada kendala yang datang atau berasal dari guru itu sendiri (faktor internal) dan ada juga kendala yang datang dari luar (faktor eksternal). Termasuk dalam faktor eksternal ini misalnya sarana dan prasarana yang dimiliki oleh sekolah, keterputusan hubungan atau komunikasi dengan orang tua tentang nilai-nilai moral yang hendak dikembangkan, dan termasuk pula di dalamnya faktor lingkungan sekitar.

Menurut Solihin, penggunaaan metode bercerita guru harus senantiasa mencari cerita-cerita yang baru guna menghindari kebosanan pada siswanya. Guru harus mampu membawakan cerita yang menarik bagi siswanya. Sementara tidak semua guru mampu membawakan cerita dengan baik. Kendala ini termasuk dalam kendala atau faktor internal. Hal inilah yang kemudian menjadikan cerita kadang hanya dimonopoli oleh kelas yang gurunya pandai bercerita. Selain kendala yang datang dari guru itu sendiri (internal), menurut Cholili( Guru Kelas II-D MINU) ada juga faktor lain yaitu kurangnya sarana atau media untuk bercerita. Misalnya, dengan menggunakan boneka kecil yang dimasukkan ke dalam tangan atau benda-benda lain sebagai media untuk memudahkan dan menarik perhatian siswa. Melalui penggunaan media dalam bercerita sebenarnya nilai-nilai multikultural yang hendak ditanamkan kepada siswa akan mudah untuk dijelaskan dan dipahami oleh siswa. Karena tidak tersedianya media bercerita yang ada terkadang cerita yang disampaikan oleh guru kurang dimengerti oleh siswa.

Untuk mengatasi berbagai kendala dalam menerapkan metode bercertia dalam menanamkan nilai-nilai multikultural kepada siswa kelas rendah, para guru telah melakukan berbagai upaya. Misalnya, menurut Husnawiyah (Guru Kelas I-A MINU), guru yang kurang mampu atau belum menguasai teknik bercerita mereka tidak segan-segan untuk senantiasa belajar, baik kepada guru yang dianggap lebih mampu atau ke lembaga di luar sekolah. Melalui saling keterbukaan di antara para guru ini mereka saling mengoreksi kekurangan guru lain, dan menjadikan kekurangan atau kelemahan yang dimiliki dapat diminimalisir. Selain itu untuk mengatasi kendala kurangnya penguasaan terhadap teknik bercerita, para guru juga belajar melalui berbagai sumber buku tentang cerita. Kendala lain yang dihadapi adalah ketika guru atau pendidik menerapkan 
metode pembiasaan dalam berperilaku. Menurut Zahratul Ula (Guru Kelas III MI Mambaul Ulum) kendala yang dihadapi misalnya kurangnya konsistensi sikap orang tua dengan apa yang diajarkan di sekolah. Demikian pula dengan perilaku yang terjadi di lingkungan rumah si anak. Di sekolah sudah diajarkan kebiasaan-kebiasaan yang baik, namun hal itu menjadi terputus ketika anak di rumah. Terkadang di rumah orang tua kurang mendukung apa yang telah dilakukan oleh guru di sekolah. Padahal antara waktu anak di rumah dan di sekolah jauh lebih banyak anak di rumah. Demikian pula ketika di sekolah dan di rumah sudah ada konsistensi dalam kebiasaan berperilaku, tetapi lingkungan sekitar dimana anak tinggal kurang mendukung atau tidak memiliki konsistensi dalam berperilaku. Upaya yang dilakukan untuk mengatasi hal itu adalah dengan mengadakan pertemuan rutin dengan orang tua wali dalam kurun waktu tertentu secara kontinyu.

\section{PENUTUP}

Dari uraian yang telah dikemukakan di atas dapat disimpulkan bahwa pendidikan untuk siswa kelas rendah yang termasuk kategori usia dini perlu untuk mendapatkan perhatian yang lebih khusus. Pendidikan yang diberikan untuk siswa kelas rendah berbeda dengan pendidikan yang diberikan untuk kelas tinggi atau orang dewasa. Kekhususan yang perlu mendapatkan perhatian, misalnya dalam merapkan metode pembelajaran, termasuk di dalamnya pemilihan metode penanaman nilai-nilai multikultural.

Berdasarkan hasil penelitian yang telah dilakukan menunjukkan bahwa metode penanaman nilai-nilai multikultural yang digunakan pada MI di bawah naungan MWCNU LP. Maarif Kecamatan Kota Kraksaan meliputi: bercerita, bermain, karyawisata, bernyanyi, outbond, pembiasaan, teladan, syair, dan diskusi. Dari beberapa metode tersebut yang paling sering digunakan adalah metode bercerita dan pembiasaan perilaku.

Metode penanaman nilai-nilai multikultural yang diterapkan banyak membawa pengaruh positif terhadap perkembangan anak dalam menerima keberagaman yang menjadi inti dari pendidikan multikultural. Melalui penghayatan isi cerita, lambat laun anak akan merubah perilakunya yang semula tidak sesuai dengan nilai-nilai multikultural yang ada menjadi lebih baik sesuai dengan tokoh yang diperankan dalam cerita. Dengan pembiasaan-pembiasaan berperilaku juga lambat laun anak akan merubah perilaku kurang baik yang kadang-kadang dibawa dari lingkungan rumahnya menjadi perilaku yang baik sesuai dengan nilai-nilai multikultural yang diharapkan, (Fauzi, 2018c).

Adapun kendala yang dihadapi oleh guruguru di lapangan ketika akan menerapkan metode penanaman nilai-nilai multikultural sangat beragam. Ada kendala yang datang atau berasal dari guru itu sendiri (faktor internal) dan ada juga kendala yang datang dari luar (faktor eksternal). Untuk mengatasi berbagai kendala dalam menerapkan metode bercerita para guru telah melakukan berbagai upaya. Misalnya guru yang kurang mampu atau belum menguasai teknik bercerita, mereka tidak segan-segan untuk senantiasa belajar baik kepada guru yang dianggap lebih mampu atau ke lembaga di luar sekolah.

Kendala lain yang dihadapi adalah ketika guru menerapkan metode pembiasaan dalam berperilaku. Kendala itu berupa inkonsistensi sikap orang tua dengan apa yang diajarkan di sekolah. Demikian pula dengan perilaku yang terjadi di lingkungan rumah si anak. Terkadang di rumah orang tua kurang mendukung apa yang telah dilakukan oleh guru di sekolah. Padahal antara waktu anak di rumah dan di sekolah jauh lebih banyak anak di rumah. Demikian pula ketika di sekolah dan di rumah sudah ada konsistensi dalam kebiasaan berperilaku, tetapi lingkungan sekitar dimana anak tinggal kurang mendukung atau tidak memiliki konsistensi dalam berperilaku. Upaya yang dilakukan untuk mengatasi hal itu adalah dengan mengadakan pertemuan rutin dengan orang tua wali dalam kurun waktu tertentu secara kontinyu.

\section{DAFTAR PUSTAKA}

Anitah, Sri. dkk. 2011. Strategi Pembelajaran di $S D$. Jakarta: Universitas Terbuka

Arikunto, Suharsimi. 2013. Prosedur Penelitian Pendidikan Suatu Pendekatan Praktik. Jakarta.Rineka Cipta Ahmad, F. (2017). Pendidikan Inklusif Berbasis Kearifan Lokal Dalam Praktik Sosial di Pesantren Zainul Hasan Genggong Probolinggo Jawa Timur. Proceedings Ancoms 1St Annual Conference For Muslim Scholars, (110), 715-725.

Baharun, H. (2016). PENDIDIKAN ANAK DALAM KELUARGA; TELAAH EPISTEMOLOGIS. Pedagogik, 3(2), 96-107.

Baharun, H. (2017). Total Moral Quality: A 
New Approach for Character Education in Pesantren. Ulumuna, 21(1), 57-80.

Baharun, H., \& Awwaliyah, R. (2017). Pendidikan Multikultural dalam Menanggulangi Narasi Islamisme di Indonesia. Jurnal Pendidikan Agama Islam (Journal of Islamic Education Studies), 5(2), 224-243.

Fauzi, A. (2009). Strategi Pengembangan Kurikulum Pendidikan Tinggi Agama Islam Swasta (PTAIS) dalam Meningkatkan Mutu Pendidikan Studi Komparatif di Universitas Muhammadiyah Malang dan Universitas Islam Malang). Universitas Islam Negeri Maulana Malik Ibrahim Malang.

Fauzi, A. (2016a). Core Values Satlogi Santri di Pesantren Zainul Hasan Genggong dalam Tantangan Globalisasi. In Prosiding Seminar Nasional \&Temu Ilmiah Jaringan Peneliti IAI Darussalam Blokagung Banyuwangi ISBN : 978-60250015-0-5. Banyuwangi.

Fauzi, A. (2016b). Transformation Of Values In Developing Leadership Prophetic Islamic Education. In 2nd ICET Theme: Improving The Quality Of Education and Training Through Strengthening Networking (pp. 1196-1204). Faculty of Education, State University of Malang.

Fauzi, A. (2017). Model Manajemen Pendidikan Islam; Telaah atas Pemikiran dan Tindakan Sosial. AtTa'lim INZAH Genggong Probolinggo, 4(Pendidikan Islam), 1-16.

Fauzi, A. (2018a). Human Resource Management dalam Meningkatkan Mutu Dosen PTKIS. At-Ta'lim INZAH Genggong Probolinggo, 4, 1(Pendidikan Islam), 21-34.

Fauzi, A. (2018b). Konstruksi Pendidikan Pesantren; Diskursus Terhadap Fundamentalisme dan Liberalisme dalam Islam. Al-Tahril IAIN Ponorogo, Vol.18(Islam: Liberalism \& Fundamentalism), 89-114.

Fauzi, A. (2018c). Transkulturasi Social Capital Pesantren; Sebagai Paradigma Pendidikan Islam Moderat. In 2St Annual Conference For Muslim Scholars, Strengthening The Moderate Vision of Indonesia Islam (Vol. II, pp. 751-765). Surabaya.

Hasan Baharun, Vidyatul Muyassaroh, Y. A. (2018). Model dan Desain Pembelajaran Inovatif, Kreatif dan Berkarakter. Probolinggo: Pustaka Nurja bekerjasama dengan Duta Media.

Cahyono, Cheppy Hari. 1995. Dimensidimensi Pendidikan Moral. Semarang IKIP Semarang Press

Dimyati \& Mudjiono. 2013. Belajar dan Pembelajaran. Jakarta: Rineka Cipta.

Hanum, Farida dan Setya Raharja. 2011. Pengembangan Model Pembelajaran Pendidikan Multikultural Menggunakan Modul Sebagai Suplemen Pelajaran IPS di Sekolah Dasar. Jurnal Penelitian Ilmu Pendidikan, Volume 04, Nomor 2. Hlm 113-128

Hidayat, Otib Satibi. 2010. Metode Pengembangan Bahasa Moral dan Nilainilai Agama. Jakarta: Universitas Terbuka

Izzati, Rita Eka dkk. 2012. Perkembangan Peserta Didik. Yogyakarta. UNY Press

Koyan, I Wayan. 2000. Pendidikan Moral Pendekatan Lintas Budaya. Jakarta: Depdiknas.

Fauzi, A. (2018). Human Resource Management dalam Meningkatkan Mutu Dosen PTKIS. At-Ta'lim INZAH Genggong Probolinggo, 4, 1(Pendidikan Islam), 21-34.

Fauzi, A. (2018). Konstruksi Pendidikan Pesantren; Diskursus Terhadap Fundamentalisme dan Liberalisme dalam Islam. Al-Tahril IAIN Ponorogo, Vol.18(Islam: Liberalism \& Fundamentalism), 89-114.

Fauzi, A. (2018). Transkulturasi Social Capital Pesantren; Sebagai Paradigma Pendidikan Islam Moderat. In 2St Annual Conference For Muslim Scholars, Strengthening The Moderate Vision of Indonesia Islam (Vol. II, pp. 751-765). Surabaya.

Kirschenbaum, H. 1995. 100 Ways To Enhance Values And Morality In Schools And Youth Settings. Massachusetts: Allyn \& Bacon.

Mahfud, Choirul. 2014. Pendidikan Multikultural. Yogyakarta. Pustaka Pelajar

Makmun, Abin Syamsuddin. 2007. Psikologi Kependidikan. Bandung: PT. Remaja Rosda Karya

Muali, C. 2017. Rasionalitas Konsepsi Budaya Nusantara dalam Menggagas Pendidikan Karakter Bangsa Multikultural. Jurnal Islam Nusantara. 1(1). 105-117

Sagala, Syaiful. 2011. Konsep dan Makna Pembelajaran. Bandung: Alfabeta.

Samani, Muchlas. 2007. Pendidikan Bermakna: Integrasi Life Skill-KBK-CTL-MBS. Surabaya: SIC 
Soesilowindradini. 2003. Psikologi Perkembangan (Masa Remaja). Surabaya: Usaha Nasional.

Sugiyono. 2014. Metode Penelitian Pendidikan Pendekatan Kuantitatif, Kualitatif, dan $R$ $\& D$. Bandung: Alfabeta

Sukarsih, Karti Hari. 2002. Media Pembelajaran dan Jenis-jenis Media Pembelajaran. Jakarta: PT Raja Grafindo Persada.

Sukmadinata, Nana Syaodih. 2013. Metode Penelitian Pendidikan. Bandung. Remaja Rosda Karya.

Sumartana, dkk. 2005. Pluralisme, Konflik, dan Pendidikan Agama di Indonesia. Yogyakarta: Interfidei

Ahmad, F. (2017). Pendidikan Inklusif Berbasis Kearifan Lokal Dalam Praktik Sosial di Pesantren Zainul Hasan Genggong Probolinggo Jawa Timur. Proceedings Ancoms 1St Annual Conference For Muslim Scholars, 2(110), 715-725.

Fauzi, A. (2009). Strategi Pengembangan Kurikulum Pendidikan Tinggi Agama Islam Swasta (PTAIS) dalam Meningkatkan Mutu Pendidikan Studi Komparatif di Universitas Muhammadiyah Malang dan Universitas Islam Malang). Universitas Islam Negeri Maulana Malik Ibrahim Malang.

Tilaar, H.A.R. 2004. Multikulturalisme: Tantangan-tantangan Global Masa Depan dalam Transformasi Pendidikan Nasional. Jakarta.Grasindo

Woolfolk, Anita. 2009. Educational Pschology. Edisi Bahasa Indonesia. Yogyakarta: Pustaka Pelajar.

Yaqin, M. Ainul. 2007. Pendidikan Multikultural Cross-Cultural Understanding untuk Demokrasi dan Keadilan. Yogyakarta: Pilar Media

Yusri, Muhammad. 2008. Prinsip Pendidikan Multikulturalisme dalam Ajaran Agamaagama di Indonesia. Jurnal Kependidikan Islam Jurusan Kependidikan Islam Fakultas Tarbiyah UIN Sunan Kalijaga Yogyakarta.Vol. 3,No.2. 